\title{
Transformations in Cuban Agriculture After $1959^{1}$
}

José Alvarez ${ }^{2}$

On October 28, 2000, U.S. President Bill Clinton signed the Trade Sanctions Reform and Export Enhancement Act (TSRA) which allowed U.S. firms to sell food and agricultural products to Cuba and other countries. However, the Cuban government did not purchase any of these products until December of 2001 following the devastating damage caused by Hurricane Michelle to important agricultural areas in November of that year.

Cuban purchases from U.S. firms amounted to $\$ 4.319$ million in 2001, \$138.635 million in 2002, and $\$ 256.9$ million in 2003. Cuba became the 35 th most important food and agricultural export market for the United States in 2003, up from last (226th) in 2000. Actual purchases and pending contracts in the first-half of 2004 are at a pace to move Cuba into the top 20 most important markets of U.S. food and agricultural exports. Furthermore, because current U.S. legislation requires that all Cuban purchases from the United States must be conducted on a cash basis, the lack of credit risk associated with these sales makes Cuba one of the most attractive export markets for U.S. firms.

Anticipating changes in U.S.-Cuba trade relations, the Food and Resource Economics
Department at UF/IFAS initiated a research initiative on Cuba in 1990, including a 1993 collaborative agreement with the University of Havana, which has lasted to this day. (Most of the resulting publications can be found at http://www.cubanag.ifas.ufl.edu). We reiterate that our role as investigators is to provide the best available information and analyses from which rational decisions can be made. The reports included in this series intend to address the increasing level of interest in the Cuban market for food and agricultural products among U.S. firms and to assist them in becoming more familiar with that market. The complete list of documents in this series can be found by conducting a topical search for "Cuba" at http://edis.ifas.ufl.edu, or under "Additional Information" at the end of this document.

\section{Introduction}

The Cuban government that took power on January 1, 1959, was going to drastically change rural Cuba. This fact sheet describes the most important agricultural policies during the 1959-1989 period, although in some instances it is necessary to mention events and policies before and after that period. A careful examination of the multitude of policies and agricultural organizations implemented during those

1. This is EDIS document FE481, a publication of the Department of Food and Resource Economics, Florida Cooperative Extension Service, UF/IFAS, University of Florida, Gainesville, FL. Published July 2004. Please visit the EDIS website at http://edis.ifas.ufl.edu.

The author would like to thank the University Press of Florida (http://www.upf.com) for permission to reproduce material from the book Cuba's Agricultural Sector (Alvarez, 2004).

2. José Alvarez, Professor, Department of Food and Resource Economics, Everglades Research and Education Center, Belle Glade, FL, Florida Cooperative Extension Service, UF/IFAS, University of Florida, Gainesville, FL.

The Institute of Food and Agricultural Sciences is an equal opportunity/affirmative action employer authorized to provide research, educational information and other services only to individuals and institutions that function without regard to race, color, sex, age, handicap, or national origin. For information on obtaining other extension publications, contact your county Cooperative Extension Service office. Florida Cooperative Extension Service/Institute of Food and Agricultural Sciences/University of Florida/Christine Taylor Waddill, Dean. 
30 years provides an understanding of the confusion arising from the fact that Karl Marx did not leave an implementation blueprint to his followers.

\section{Brief Historical Background}

It was evident that, being the most important sector of the Cuban economy, agriculture was to experience drastic and continuing transformations under the leadership that took power on January 1, 1959. These transformations originated in the agrarian struggles that were supported by most sectors of Cuban society before the revolution.

Although most authors only cite the two agrarian reform laws of 1959 and 1963, the agrarian revolution in Cuba originated in the mountains of the Sierra Maestra when Law No. 3 of the Rebel Army was promulgated in October of 1958. The basic principle of the law was that the land should be given to those who tilled it. Thus, the 1958 law revolved around the idea of massive land distribution.

Domínguez (1978) states that prior to 1959, less than one-tenth of the Cuban peasants lacked legal claim to the land they tilled. These squatters were mainly concentrated in the province of Oriente, the focal point of Castro's guerrilla warfare. And Domínguez adds:

This more or less accidental event brought the leaders of the revolution in contact with what was essentially an atypical rural dweller. The revolutionary government's policies in 1959 and thereafter were influenced by this experience, a fact that explains why so much of their early legislation was devoted to solving the problems of Cuba's few squatters, while the many more peasants who were not squatters and the even more numerous agricultural workers received less government attention (pp. 423-424).

Law No. 3 was implemented in all territories occupied by the Rebel Army. Although free land was distributed among farmers who tilled up to 28 hectares, with the right to purchase up to 67 hectares, it did not proscribe the latifundia, leaving its elimination to a future government (Valdés Paz, 1997, p. 53).

\section{The Agrarian Reform Law of 1959}

\section{Objectives and Articles}

The first Agrarian Reform Law was enacted on May 17, 1959, by the revolutionary government. As a symbolic gesture, it was signed into law in the mountains of the Sierra Maestra. It proscribed latifundia (defined as estates larger than 402 hectares) and it initially distributed some land and encouraged the development of cooperatives on larger estates. It did not, however, break up the large sugarcane plantations and cattle ranches. Thomas (1971, pp. 1216-1217) explains that Castro had already changed his mind regarding distribution of land by the time of the 1959 Agrarian Reform Law. He believed that, rather than dividing latifundios into small plots (which would decrease production), they should maintain larger tracts of land under governmental control.

The 1959 Agrarian Reform Law represented a drastic change from the 1958 Rebel Army's approach of massive land distribution. The main objectives of the law can be summarized as follows:

- to ensure progress through growth and diversification (eliminating dependence on monoculture).

- to make full use of natural and human resources.

- to diversify agricultural and livestock production.

- to stimulate industrial development through state and private means.

- to augment and diversify agricultural production to expand exports, supply raw materials for the national industry, and satisfy domestic consumption.

- to modify the agrarian structure by proscribing latifundia, eliminating certain forms of exploitation (e.g., sharecropping), and granting land ownership to those who worked it to ensure a greater use of land resources.

- to substitute latifundia production with more technical and efficient production forms such as cooperatives. 
- to establish an agricultural organization capable of implementing the law and to create objectives of economic and social development that conform to the law.

- to prevent future control by foreigners of the national rural patrimony.

According to Valdés Paz (1997, p. 63), the previous goals were intended to reconcile the interests of different social classes and groups interested in change (e.g., the rural and urban proletariat, the peasantry, the progressive rural and urban bourgeoisie, and the middle classes, among others). The only ones adversely affected were the sugar bourgeoisie; the importing bourgeoisie; and the holders of foreign capital invested in agriculture, sugar, and foreign trade.

The main body of the law was composed of nine chapters and 77 articles that proclaimed:

- the proscription of latifundia (single owners could own up to 402 hectares; large farms with intensive production could own up to 1,340 hectares).

- the proscription of "administration cane" (cane owned by natural or juridical persons for grinding in their own mill), and the expropriation of land owned by such plantations.

- compensation for the properties affected by the law, with payments to be made in 20 -year bonds bearing an annual interest of $4.5 \%$.

- the proscription of foreign ownership of rural property.

- the distribution of land to those who till it, establishing priorities for the different lands as well as priorities among the beneficiaries.

- a "vital minimum" size of parcels (the minimum amount of land needed for the support of a peasant family) of up to 27 hectares; parcels of this size were to be distributed to peasants (the parcels could only be transferred by inheritance and were not divisible).
- the prohibition of land possession other than by ownership.

- the recuperation of state lands, especially those that had not been properly registered by 1958 .

- the right to agrarian cooperation, including agricultural cooperatives, which, in the case of state lands, would be under the management of the National Institute of Agrarian Reform (Instituto Nacional de Reforma Agraria,INRA) and, in the case of private lands, would receive all support needed from INRA.

- the establishment of Agricultural Development Zones that would act as administrative units of the agrarian reform and as centers of social, economic, and agrarian development activities.

- the creation of institutions in charge of implementing the Law of Agrarian Reform (to incorporate it into the Fundamental Law of the Republic to give it the force of constitutional law), the establishment of INRA, and the creation of land tribunals to solve the juridical problems derived from the implementation of the law.

- the conservation of forests and soils.

- the enumeration of other dispositions (e.g., prohibiting farmers' evictions, suspending pending trials, establishing a two-year period to place all private lands into production, etc.).

\section{Impact on Land Tenure and Structure}

The impact of the 1959 Agrarian Reform Law on land tenure and structure was significant. All 9.1 million hectares of land in 1958 were in private hands and almost $43 \%$ of the land was in farms over 402 hectares. Two years after the first agrarian reform law, land in the private sector had declined to $58.4 \%$, with the remaining $41.6 \%$ under state control. Farms over 402 hectares in size (i.e., 300 People's Farms, totaling 2,576,000 hectares) were under state control as proscribed by the 1959 Agrarian Reform Law. The previous classification by Mears (1962, p. 13) assumes that the 630 cooperatives established under the law were under state control and, for that reason, are classified as state-owned farms. 
If the 630 agricultural cooperatives are considered as privately-owned farms, then in 1961, the private sector owned $72 \%$ and the state owned $28 \%$ of the agricultural land. This breakdown appears to be more appropriate. As a matter of fact, this disparity was one of the reasons leading to a second agrarian reform law four years after the enactment of the first one.

Even by western standards and despite its impacts on the structure of land tenure, Cuba's first agrarian reform was not a radical one. According to Thomas (1971, p. 1217), many of the Eastern European reforms of the 1920 s went further than the Cuban agrarian ideas of 1959. For example, the maximum amount of land allowed by a single owner in Poland and Bulgaria was 20 hectares and 49 hectares, respectively.

\section{A Two-Year Evaluation}

The President of INRA conducted an evaluation of the general impact of the 1959 Agrarian Reform Law and its subsequent legislation at the time of its second anniversary (Núñez Jiménez, 1961). His findings are as follows:

- The large sugarcane estates had been converted into 622 sugarcane cooperatives while the large cattle ranches and rice plantations had been converted into 263 People's farms.

- 31,425 title deeds to land parcels of 28 hectares or less had been handed over for free to the poorest peasants.

- Law No. 851 of 1960 distributed 1,260,000 hectares of nationalized U.S. properties in Cuba among 596 sugarcane farms while Law No. 890 of 1960 expropriated 2,533 sugarcane farms (909,200 hectares) owned by Cuban firms.

- INRA's rural housing department built over 500 public buildings (e.g., schools, hospitals, stores, community centers, and theaters) in only one year.

- There were 1,996 retail People's stores (selling a variety of items at subsidized prices), 25 large warehouses, and 58 subsidiary warehouses.
- A variety of productive, social, and cultural services had been increased or had reached the peasants for the first time, including credit, machinery, schools, cultural centers, housing, medical services, and rural electrification.

\section{A Four-Year Evaluation}

This evaluation was conducted by the new President of INRA, Carlos Rafael Rodríguez (1963). Not much is contained in this new assessment. Rodríguez repeats many of the success stories and background material of the first evaluation.

Of particular interest, however, is his explanation of the circumstances causing the food shortage in 1962, leading to the establishment of a rationing system (EDIS FE482) that still exists today. Despite the explanations given, he also states that, "as Fidel Castro has said, this is the only agrarian reform in which production did not drop with the reform. This is true until the end of 1961, and it is true for agricultural-livestock production as a whole, except for sugarcane, until 1962" (1963, p. 26).

\section{The Process of Socialization Continues}

On August 6, 1960, President Dorticós and Premier Castro signed Resolution No. 1 which, in retaliation for the suspension of the U.S. Cuban sugar quota, expropriated U.S. enterprises, including 21 sugar mills and their lands. On October 13, 1960, Law No. 890 responded to the U.S. embargo by expropriating, among others, the remaining 105 sugar mills and 16 rice mills with their lands. On October 24, 1960, Resolution No. 3, signed by President Dorticós and Premier Castro, nationalized the remaining U.S. enterprises (Alvarez, 1990, pp. 103, 121). Numerous resolutions, signed by the Ministry for the Recovery of Misappropriated Property since early January of 1959, had confiscated the assets (including numerous farms) of members of the previous government (who had acquired them with public funds). Total land affected under the different measures amounted to over 4.4 million hectares (Valdés Paz, 1997, p. 81). The nationalization of U.S. properties eliminated the foreign presence in Cuba's countryside, consistent with the 1959 Agrarian Reform Law. 


\section{Establishment of ANAP and Agricultural Associations}

The process of reform and power consolidation in the rural areas continued with the establishment of the National Association of Small Farmers (Asociación Nacional de Agricultores Pequeños, ANAP) in May of 1961, with membership restricted to farmers with fewer than 67 hectares and to larger farmers who had demonstrated allegiance to the revolution. Its membership surpassed 200,000, accounting for almost one-third of the economically-active rural population.

Aranda (1968) reports that the results of the (July) 1965 Agricultural Census found around 2.7 million hectares among 200,000 farms in what he calls the private sector (nonstate sector). The labor force in this sector included 290,000 men and women and their family members plus 36,000 permanent workers and seasonal workers (pp. 147-148). These figures changed afterwards, however. Agricultural Production Cooperatives (CPAs) were established 10 years after the 1965 Agricultural Census and became part of what was called the socialist sector.

Meanwhile, the number of peasants with small parcels (сописоs) producing for family consumption, bartering, or sales in the black market is not known. Deere et al. (1995) acknowledge that the 1987 Census of private sector land revealed that the amount of land held by the non-peasant sector was not insignificant and that it had been previously underestimated in official data.

At the same time that the ANAP was established, the Cuban government began a widespread campaign to encourage "agricultural associations" (Asociaciones Campesinas) in the nonstate sector. Small farmers not in the vicinity of large farms and cooperatives were urged to pool their land and other resources with their neighbors to form agricultural associations. Some of these units were to be small (in the range of 40 to 53.6 hectares). Apparently, the term "association" was used instead of cooperative because of the farmers' reluctance to become cooperative members (Mears, 1962, p. 13). Castro reported that nearly 300 of these associations had been created by 1963 (Castro, 1963, p. 12).
Also, by 1963, the armed struggle initiated in the rural areas in 1959 had been reduced to a minimum. It was time to continue with the process of socialization in the countryside. The government was ready for its second agrarian reform law.

\section{The Agrarian Reform Law of 1963}

A second Agrarian Reform Law was enacted in October of 1963. It expropriated the land of most farmers with more than 67 hectares, bringing $70 \%$ of the lands under government control. The only exceptions on the limit were farms worked by several brothers together, each with a per capita area below the 67 hectare limit, and cases considered by INRA as exceptional (high productivity and a willingness to cooperate with the state agricultural plans).

The reasons behind this new law were twofold: (1) socialist property ownership had advanced farther in other sectors of the economy, although limits on land ownership were considered unacceptable; and (2) the rural bourgeoisie was in conflict with the revolutionary process, helping armed groups fighting the government (Aranda, 1968, p. 189).

The first drastic measure of the agrarian revolution (1959 Agrarian Reform Law) only affected land belonging to foreign companies and large Cuban owners while the 1963 Agrarian Reform Law only impacted medium-size Cuban farmers.

Farmers anticipated the 1963 law and "distributed" their lands among members of their immediate and extended families (a process whereby the peasant economy is a "refuge" whereby common law anticipates statute law). Forster (1989) described this attitude in the following way:

During the early years of the revolution as they faced expropriation, large farmers decapitalized their holdings, failed to maintain irrigation and machinery, slaughtered their animal herds, and otherwise adversely affected production for years to come. Even after the 1963 Agrarian Reform, it is likely that farmers in the remaining private sector were hesitant to invest heavily until they were sure that they, too, would not be expropriated (p. 239). 
After the 1963 Agrarian Reform Law, the Cuban leadership was in a constant search for the best ways to organize production along socialist lines and the type of incentive system that would better correspond to each type of organization. The following sections describe that process for the period ending in 1993.

\section{Types of Agricultural Organizations}

\section{Agricultural Production Cooperatives (CPAs)}

During the 1960s and early 1970s, the Cuban leadership did not emphasize the establishment of agricultural cooperatives. On May 17, 1974, during his speech on the 15th anniversary of the 1959 (first) Agrarian Reform Law, Castro expressed the view that it was about time for private farmers to put their 1.5 million hectares into superior forms of production for land socialization (Pampín Balado and Trujillo Rodríguez, n.d.). He also stated that the process of socializing the lands of independent farmers would be a long one, culminating in the day when there would no longer be any independent peasants.

The Agricultural Production Cooperatives (CPA) are defined as "a superior form of collective production of social property which were started after the farmers' decision to join their lands and other fundamental means of production" (CEE, 1989, p. 178).

Although Agricultural Production Cooperatives (CPAs) began in 1975, Law No. 36 of Agricultural Cooperatives was not enacted until August 24, 1982. It is important to point out that the law referred to two types of cooperatives: Agricultural Production Cooperatives (CPAs) and Cooperatives of Credit and Services (CCSs), which are discussed below. Pollitt explains the reasons for the establishment of CPAs in the following manner:

The CPAs had come about for reasons familiar to historians of socialist agriculture. By pooling their holdings in larger enterprises, it was argued that individual farmers achieved economies of scale through rational, specialized use of land and labor combined with modern means and methods of production. Socially, the concentration of dispersed peasant households simplified the provision of electricity; sanitation; and better housing, schools and medical care (1996, p. 23).

In terms of the CPAs, the law described the main goals of this type of organization as follows:

- to develop agricultural and livestock production within the social goals and interests of the cooperative.

- to consolidate and increase the social exploitation of the cooperative's assets.

- to increase labor productivity and the efficiency of social production.

- to increase production and sales of agricultural products to the state.

- to foster the best application of technology and science within a socialist form of production.

- to help in the fulfillment of the growing material and cultural needs of the cooperatives and their families, to stimulate their participation in the different aspects of social life, and to contribute to increase the standard of living and the establishment of socialist living relations among its members.

- to advance socialist emulation.

- to develop the participation of the cooperative members and their families in the economic, political, and social tasks of the country.

Material incentives for CPA members involved profit sharing of net returns (Meurs, 1990, p. 120):

-40-50\%: distributed at the end of the year among members according to the amount of work performed.

-25-30\%: paid to members for the land and equipment contributed when the cooperative was created.

-10\%: placed in a investment fund.

- 5\%: put into "cultural" development (e.g., establishing daycare facilities). 
The 1,378 CPAs that were established by 1985 , including $63 \%$ of independent farmers, controlled slightly over one million hectares. Also, by 1985 , about 19,156 individual houses had been built and 882 cooperatives had received electricity. As a result, the agricultural associations disappeared.

In 1993, the number of CPAs had decreased to 1,219 and their area to 772,500 hectares. There were 60,266 cooperative members, with an average of 50 members per cooperative (CEE, 1998, p. 179).

CPAs were praised by the government as examples of "good management" until the advent of Cuba's economic crisis in the 1990s. A summary report (ISCAH, n.d.) shows sugarcane and non-sugarcane cooperatives with positive returns over long periods of time. The report also exhibits a decreasing number of CPAs until the 1990s.

\section{Cooperatives of Credit and Services (CCSs)}

The Cooperatives of Credit and Services (CCSs) are "primary organizations of a collective nature that allow the public use of irrigation, some facilities, services and other means, as well as the transacting of their credits although the property of each farm, its equipment and resulting production remains private" (CEE, 1989, p. 178).

Although this type of agricultural organization was part of the law that established the CPAs, some had already been created, mainly in the tobacco region of the Pinar del Río province, after the enactment of the first Agrarian Reform Law in 1959 and the creation of ANAP in 1961. In fact, by mid-1963, there were 527 CCSs with over 46,000 members and 433,000 hectares. Just one year later, their number had grown to 899 cooperatives with close to 56,000 members and 527,000 hectares. By 1967, the numbers had increased to 1,119 cooperatives with almost 78,000 members and 697,000 hectares. Until 1976, ANAP devoted most of its efforts to the consolidation of the CCS movement and subsequently shifted its emphasis to the CPAs. As a result, the CCSs lost momentum. By1982, their number had declined to 2,181 . In 1998 , there were 2,781 cooperatives with 163,800 members and 962,300 hectares (CEE, 1998).
CCSs are mainly established to share the use of credit and some inputs and services (e.g., seed, fertilizer, and chemical products). Occasionally, they also acquire tractors, trucks, pumps, and other types of machinery and equipment. They can also devote themselves to the building of collective projects such as dams and warehouses.

The demise of the old agricultural production model at the end of 1993 prevented CCSs from continuing to obtain the services frequently offered by state enterprises. New means to guarantee their existence had to be found. The CCSs were authorized to purchase the means of production for collective use and to hire permanent laborers for the benefit of the collective. Their organization was later changed to adapt to the strict scarcity situation that developed at the beginning of the 1990s (Arias Guevara and Hernández Benítez, 1998, p. 30).

\section{Independent (Dispersed) Farmers}

Independent (dispersed) small private producers are those who farm their own land with family labor and establish commitments with the state to sell their agricultural products to the state collection agency, Acopio. In return, the state sells them agricultural inputs. Although there were more than 200,000 independent farmers in the mid-1960s (Aranda, 1968), their numbers declined after the establishment of the CPAs in the mid-1970s and, by the time the reform process started in 1993, they only controlled $9 \%$ of the agricultural land.

There are numerous examples that reflect the doctrinal preference of the Cuban leadership for collective farms (state control) over cooperative farms (social or community control) or private ownership of the agricultural means of production. That preference appeared in the early 1960s and was not based on relative performance efficiency by types of enterprises but on purely ideological grounds (Dumont, 1971, pp. 29-31, 50-51). Research has shown that the relative order of priorities to receive inputs and assistance from the state was state farms, CPAs, CCSs, and finally independent farmers (Alvarez and Puerta, 1994). 


\section{Concluding Observations}

It should be noted that state farms, CPAs, and CCSs, let alone independent (dispersed) farmers, have not typically had the freedom to select what crops or commodities to produce. Consistent with Cuba's centrally planned economic system such decisions are made by government bureaucrats after discussions with the interested party. Also, the government establishes production quotas that each farm is obligated to sell to the state collection agency, Acopio (EDIS FE484), at prices established by the government, which are typically quite low. It is readily apparent that such a system provided little incentive for expanded agricultural production throughout the first 30 years following the revolution.

Another fact sheet in this series entitled, Antecedents of the Cuban Agricultural Policies of the 1990s (EDIS FE485), discusses more recent and, in some cases, significant modifications to the form and function of Cuba's agricultural organizations.

\section{References}

Alvarez, José. 1990. A Chronology of Three Decades of Centralized Economic Planning in Cuba." Communist Economies 2: 101-125.

Alvarez, José. 2004. Cuba's Agricultural Sector. Gainesville, FL: University Press of Florida.

Alvarez, José, and Ricardo A. Puerta. 1994. State Intervention in Cuban Agriculture: Impact on Organization and Performance. World Development 12 (11): 1663-1675.

Aranda, Sergio. 1968. La Revolución Agraria en Cuba. Mexico, DF: Editorial Siglo XXI.

Arias Guevara, María de los A. and Raciel Hernández Benítez. 1998. "Tendencias Actuales en las CCS. Visión Desde un Estudio de Caso (CCS "Pedro Blanco" Holguín)." In Campesinado y Participación Social, complied by Niurka Pérez Rojas, Ernel González Mastrapa and Miriam García Aguiar, pp. 30-38. La Habana: Universidad de la Habana.
Castro, Fidel.1963. Cuba's Agrarian Reform: A Speech by Dr. Fidel Castro. Toronto, Canada: Fair Play for Cuba Committee (January).

CEE. Comité Estatal de Estadística. Annual Issues. Anuario Estadístico de Cuba. La Habana: Editorial Estadística.

Deere, Carmen Diana, Ernel González, Niurka Pérez, and Gustavo Rodríguez.1995. The View From Below: Cuban Agriculture in the 'Special Period in Peacetime.' Journal of Peasant Studies 21 (2, January): 194-234.

Domínguez, Jorge I. 1978. Cuba - Order and Revolution. Cambridge, MA: Harvard University Press.

Dumont, Rene. 1971. Cuba, ¿Es Socialista?, 2d edition. Caracas, Venezuela: Editorial Tiempo Nuevo.

Forster, Nancy. 1989. Cuban Agricultural Productivity. In Cuban Communism, edited by I.L. Horowitz, pp. 235-255. New Brunswick, NJ: Transaction Publishers.

ISCAH. Instituto Superior de Ciencias Agropecuarias de la Habana. n.d. Informe Sobre Cooperativas y sus Resultados Económicos. Polo Científico de Humanidades, Grupo de Estudios Socio-económicos de Producción Cooperativa y Campesina. La Habana.

Mears, Leon G. 1962. Agriculture and Food Situation in Cuba. ERS-Foreign 28, Economic Research Service, United States Department of Agriculture, Washington, D.C. (May).

Meurs, Mieke.1990. Agricultural Production Cooperatives and Cuban Socialism: New Approaches to Agricultural Development. In Transformation and Struggle - Cuba Faces the 1990s, edited by Sandor Halebsky and John M. Kirk, pp. 115-130. New York, NY: Praeger.

Núñez Jiménez, Antonio. 1961. In the 2nd Year of the Cuban Agrarian Reform. La Habana: Editorial En Marcha.

Pampín Balado, Blanca Rosa and Clara María Trujillo Rodríguez. n.d. Los Cambios Estructurales 
en la Agricultura Cubana. La Habana: Asociación Nacional de Economistas de Cuba.

Pollit, Brian H. 1996. Collapse, Reform and Recovery Prospects of the Cuban Sugar Economy. Occasional Paper No. 62-1996, Institute of Latin American Studies, University of Glasgow.

Rodríguez, Carlos Rafael. 1963. Four Years of Agrarian Reform. La Habana: Ministry of Foreign Relations.

Thomas, Hugh. 1971. Cuba: The Pursuit of Freedom. New York, NY: Harper \& Row.

Valdés Paz, Juan. 1997. Procesos Agrarios en Cuba, 1959-1995. La Habana: Editorial de Ciencias Sociales.

\section{Additional Information}

Below is a list of the fact sheets in this series on Cuban Agriculture. They can be accessed by clicking on the highlighted links:

- FE479 - Cuban Agriculture Before 1959: The Political and Economic Situations

- FE480 - Cuban Agriculture Before 1959: The Social Situation

- FE481 - Transformations in Cuban Agriculture After 1959

- FE482 - Overview of Cuba's Food Rationing System

- FE483 - The Issue of Food Security in Cuba

- FE484 - Acopio: Cuba's State Procurement and Distribution Agency

- FE485 - Antecedents of the Cuban Agricultural Policies of the 1990s

- FE486 - Chronology of Cuban Reform Policies with Emphasis on Agriculture, 1993-1995

- FE487 - Cuba's Basic Units of Cooperative Production
- FE488 - Cuba's Agricultural Markets

- FE489 - Environmental Deterioration and Conservation in Cuban Agriculture

- FE490 - The Potential Correlation between Natural Disasters and Cuba's Agricultural Performance 